\title{
Inflammatory pseudotumor-like follicular dendritic cell tumor: an underdiagnosed neoplasia
}

\author{
Aline Caldart Tregnago, Diogo Lago Morbeck, Felipe D’Almeida Costa, Antonio Hugo José Froes M. Campos, \\ Fernando Augusto Soares and José Vassallo* (D)
}

\begin{abstract}
Follicular dendritic cell (FDC) tumor is an uncommon neoplasm. It generally presents as a slow-growing, painless mass, without systemic symptoms. Histological features usually include low grade spindle cell proliferation. This tumor occurs primarily in lymph nodes, especially cervical and axillary, however, involvement of extranodal sites such as the tonsils, spleen, liver, and gastrointestinal tract has been reported. Inflammatory pseudotumor-like follicular dendritic cell tumor (IPT-like FDCT) is a rare, distinctive histological subtype of this low-grade malignant neoplasm, with consistent Epstein-Barr virus (EBV) association. The differential diagnosis with other fibro-inflammatory tumor proliferations, as inflammatory pseudotumor (IPT) and inflammatory myofibroblastic tumor (IMT), may be challenging. In the present article, two cases of IPT-like FDCT of the spleen are presented, with a broad overview of the literature: one 77-year-old male and one 70-year-old female. A large immunohistochemical panel should be used for diagnosis, as no single specific and totally sensitive markers are available, including markers for CD21, CD23, CD35, CNA42, and clusterin. Individual cases may express one or more of these markers, so that all of them should be investigated. In situ hybridization for EBV is constantly positive. Immunostaining for ALK should be negative, as it is present in roughly half of the cases of IMT. This panel should be used in combination of clinical, laboratory, and topographic evidences. Importantly, inclusion of this lesion as a possible option in clinical and pathological investigation represents the basis for a correct diagnosis.
\end{abstract}

Keywords: Spleen, Inflammatory pseudotumor, Inflammatory myofibroblastic tumor, Follicular dendritic cell tumor, Inflammatory pseudotumor-like follicular dendritic cell tumor

\section{Background}

Follicular dendritic cell (FDC) tumor is an uncommon neoplasm, which typically presents as a slow-growing, painless mass, without systemic symptoms. This tumor occurs primarily in lymph nodes, especially cervical and axillary, however, involvement of extranodal sites such as the tonsils, spleen, and gastrointestinal tract has been reported [1]. Lung involvement typically represents metastatic disease. FDC tumors mainly affect young to middle-aged patients, without gender predilection. The clinical course tends to be indolent, but intra-abdominal tumors may have an aggressive progression $[2,3]$. This

\footnotetext{
* Correspondence: vassallomeister@gmail.com

Department of Anatomic Pathology, AC Camargo Cancer Center, R. Prof.

Antônio Prudente, 211-Liberdade, Zip Code, São Paulo, SP 01509-010, Brazil
}

tumor is classified together with other histiocytic and reticulum cell tumors (Table 1) [4-10].

Inflammatory pseudotumor-like follicular dendritic cell tumor (IPT-like FDCT) is a rare, distinctive histological subtype of this low-grade malignant neoplasm, with consistent Epstein-Barr virus (EBV) association. It presents similar morphology and displays clinical and pathological characteristics intermediate between inflammatory pseudotumor (IPT) and follicular dendritic cell (FDC) tumor. This makes this entity challenging, not only for histopathological diagnosis but also for clinical treatment, as this entity can be much more indolent than conventional FDC sarcoma [11].

IPT is an infrequent lesion of unknown histogenesis. It presumably corresponds to nonneoplastic, hematopoietic, spindle fibrous proliferation, which may occur in a variety 
Table 1 Histiocytic and reticulum cell neoplasia: overview

\begin{tabular}{|c|c|c|}
\hline & Immunohistochemical profile & Clinical course \\
\hline Langerhans cell histocytosis and & $\begin{array}{l}\text { CD1a+; S100 protein+; CD68-/+; lisozime-; CD21/CD35-; } \\
\text { EBV- }^{-1} \text { [Birbeck granules+] }\end{array}$ & $\begin{array}{l}\text { Variable clinical presentation: localized indolent } \\
\text { to systemic aggressive }\end{array}$ \\
\hline Langerhans cell sarcoma & & Agressive \\
\hline Indeterminate dendritic cell tumor & $\begin{array}{l}\text { CD1a+; CD4+; Fascin+; S100+; CD68+/-; langerin } \\
\text { [Birbeck granules-]- }\end{array}$ & Most frequently localized \\
\hline Interdigitating reticulum cell tumor & $\begin{array}{l}\text { Positive: } \mathrm{S} 100 \text { protein, fascin; Frequently positive: } \\
\text { CD4, CD11C, CD14, CD45, CD68, HLA-DR, lisozime, } \\
\text { EMA; Negative: CD1a, langerin, CD21/CD35, CD23 }\end{array}$ & Mostly lymph nodes; very aggressive \\
\hline Follicular dendritic cell tumor & $\begin{array}{l}\text { Positive: CD21/CD35, CD23, KiM4p, CNA42, clusterin, } \\
\text { D2.40 (membrane), desmoplakin, fascin, EGFR, HLA-DR; } \\
\text { Sometimes positive: CD4, CD11a, CD14, CD20, CD45, } \\
\text { CD68, EMA, S100 protein, smooth muscle actin; IPT-like } \\
\text { cases consistently EBV+; Negative: CD1a, CD3, CD34, } \\
\text { CD79a, myeloperoxidase, lisozime, HMB45 }\end{array}$ & $\begin{array}{l}\text { Mostly lymph nodes; middle age around the } \\
\text { 5th decade; one third extranodal; moderately } \\
\text { aggressive. } \\
\text { IPT-like cases mostly liver and spleen, female } \\
\text { patients, more indolent course. }\end{array}$ \\
\hline $\begin{array}{l}\text { Fibroblastic reticular cell tumor / CIRC } \\
\text { (cytokeratin positive interstitial reticular } \\
\text { cell) tumor }\end{array}$ & $\begin{array}{l}\text { Positive: Vimentin; CIRC: cytokeratins, EMA, CD21, } \\
\text { fascin; Frequently positive: smooth muscle actin, desmin, } \\
\text { factor XIlla; Negative: CD35, D2.40, CD1a, S100, EBV }\end{array}$ & Indolent (localized cases) to aggressive \\
\hline Histiocytic sarcoma & $\begin{array}{l}\text { Positive: CD68, CD163, CD4, CD11C, CD14, lysozyme; } \\
\text { Negative: B and T cell markers, CD30, EMA, CD21, CD23, } \\
\text { CD35, CD1a, langerin/CD207, CD13, CD33, myeloperoxidase, } \\
\text { cytokeratins, HMB45; S100 protein positive in 50\% cases }\end{array}$ & $\begin{array}{l}\text { Frequently extranodal; } \\
\text { Mostly aggressive }\end{array}$ \\
\hline
\end{tabular}

Based on References [4-10]; 1: see Reference [5]; 2: see Reference [8]

of anatomic sites. More recently it has been shown that most lung IPTs correspond, in fact, to inflammatory myofiboblastic tumors (IMT). There are no specific clinical and imaging findings. From the pathologic point of view, there are no immunohistochemical markers for IPT, and it is frequently diagnosed in the absence of markers for FCD tumor. Patients of middle to advanced age are affected, without relation to gender. Prognosis is favorable after excision [2, 3, 12-14].

IPT-like FDCT has been recently divided into two morphological variants: granulomatous and eosinophilrich. These variants mimic inflammatory or infective lesions, leading to misdiagnoses [15]. The purpose of the present review is to discuss the differential diagnoses and to exemplify this entity, by reporting two more cases of the granulomatous variant of IPT-like FDCT. It is expected to stress the importance of including this differential diagnosis in fibro-histiocytic proliferations with remarkable inflammatory infiltrate.

\section{Main text}

Two illustrative cases of inflammatory Pseudotumor-like follicular dendritic cell tumor

In the first case, a seventy-seven-year-old male presented with asthenia, abdominal pain, $11 \mathrm{~kg}$ weight loss, and constipation. Medical history included previous prostatectomy due to cancer 14 years earlier and ongoing treatment for hypertension and diabetes mellitus type II. Abdominal computed tomography (CT) revealed a slightly hypodense splenic mass, measuring $6.0 \times 5.7 \times$ $4.6 \mathrm{~cm}$, with regular contours and heterogeneous contrast enhancement. Splenectomy was indicated. Grossly, the spleen weighed $308 \mathrm{~g}$ and measured $14 \times$ $13 \times 9 \mathrm{~cm}$. Cut surface displayed a grayish, well-defined solid lesion, measuring $8.0 \mathrm{~cm}$ in maximum diameter.

In the second case, an asymptomatic seventy-year-old woman was submitted to a positron emission tomography (PET) scan, as a routine follow-up examination for breast cancer, which had been diagnosed and treated 4 years before. She was in current use of Tamoxifen. A spleen lesion was found, and a splenectomy was performed. Grossly, the spleen weighed $70 \mathrm{~g}$ and measured $10 \times 6 \times 4 \mathrm{~cm}$. There was a grayish, well-defined solid lesion, measuring $4.0 \mathrm{~cm}$ in maximum diameter.

Histologically, both cases exhibited a well defined, nonencapsulated proliferation composed of noncaseating epithelioid granulomas distributed regularly throughout the lesion. The granulomas were composed of epithelioid histiocytes, giant cells, mature lymphocytes and plasma cells. In case 1 , the number of plasma cells was particularly high (Figs. 1 and 2). There were areas with scattered ovoid cells, with focal vague fascicular pattern. These cells had pale cytoplasm with indistinct borders, elongated to oval nuclei, thin evident nuclear membrane, finely dispersed chromatin, and central eosinophilic nucleoli: the neoplastic follicular dendritic reticulum cells (Fig. 3). No mitotic figures, or cell atypia were identified. There were no eosinophils, neutrophils, or necrosis. Foci of fibrosis were seen (Figs. 1 and 2). Fungi (Grocott staining) and alcohol-acid fast bacilli (Ziehl-Neelsen staining) were not detected.

A large panel of immunohistochemical markers was performed, as well as chromogenic in situ hybridization 


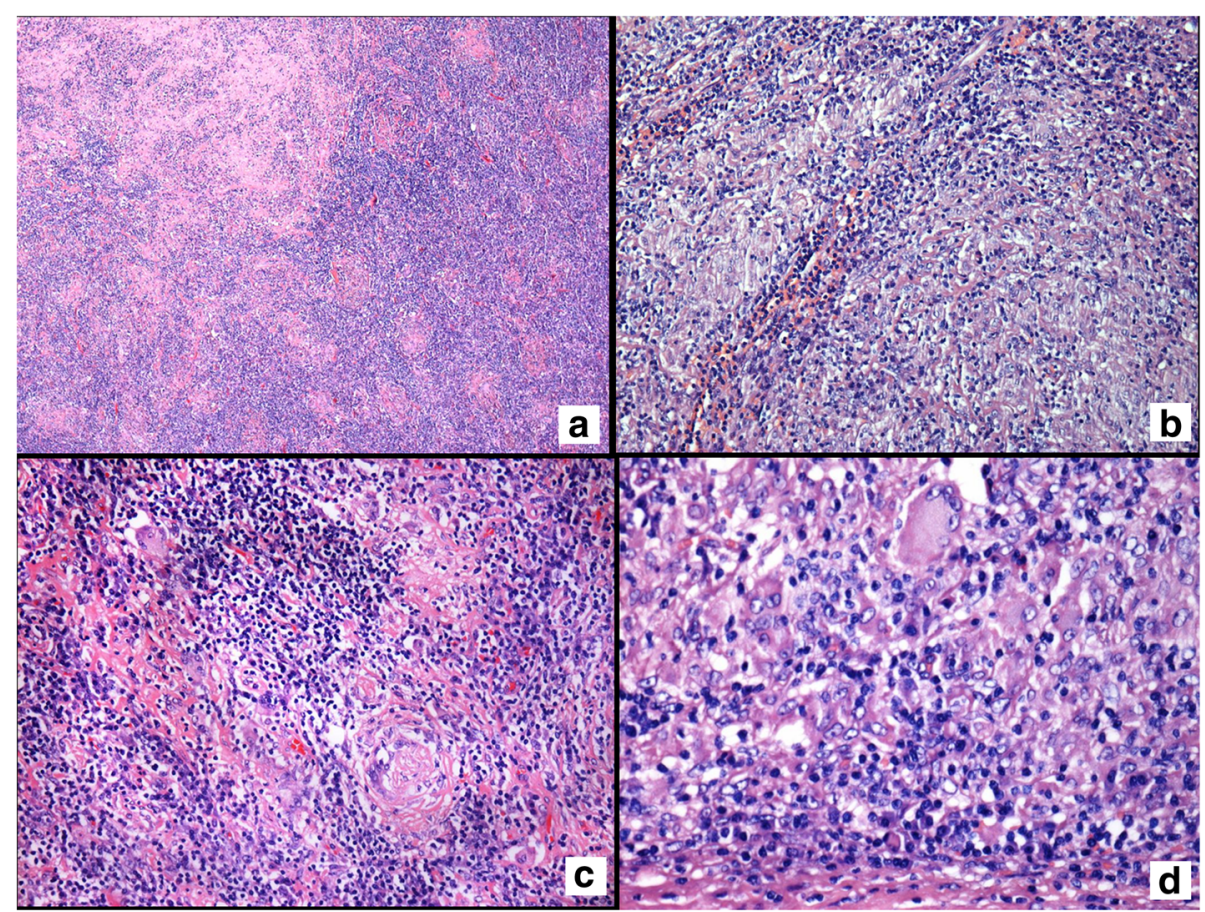

Fig. 1 Splenic IPT-like dendritic cell tumor. (a, b) Inflammatory cells with clusters of epithelioid hystiocytes predominate; irregular fibrotic bands are present. (c) Focal fibrosis and (d) scattered multinucleated giant cells are also observed. [H\&E, original magnification $A=100 \times, B$ and $C=200 \times, D=400 \times$ ]

(CISH) for EBV-encoded RNA (EBER). Both techniques were carried out in a BenchMark XT system (equipment and reagents provided by Ventana Medical Systems Inc., Tucson, AZ, USA). The proliferated spindle shaped cells were positive for $\mathrm{CD} 21$ and/or CD23, at least focally
(Fig. 4-A and B), and negative for CD20, CD3, ALK, S100 protein, smooth muscle actin, CD34 and C-Kit. In both cases neoplastic follicular dendritic reticulum cells were highlighted by in situ hybridization for EBV (Fig. 4-C and D).

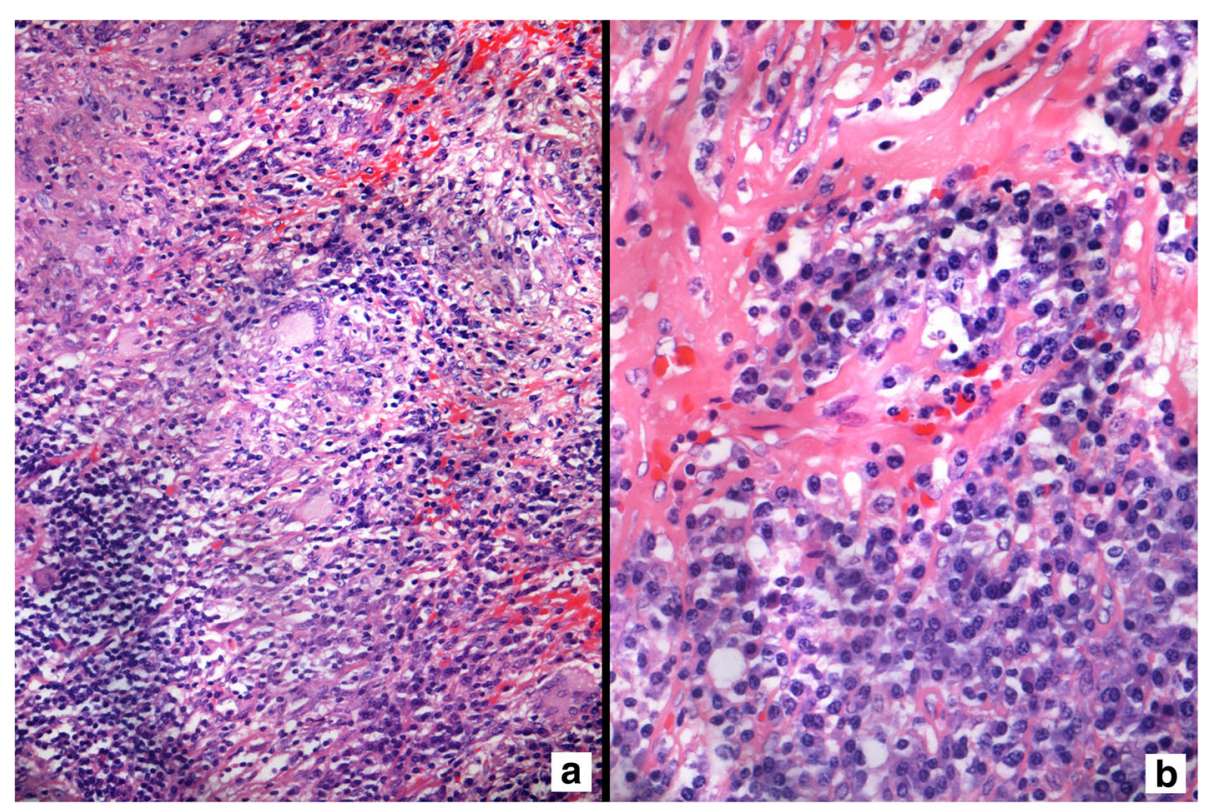

Fig. 2 Splenic IPT-like dendritic cell tumor. (a) Inflammatory cells, clusters of epithelioid hystiocytes, scattered multinucleated giant cells and focal fibrosis. (b) This area contains fibrotic bands and sheets of plasma cells. [H\&E, original magnification $A=200 \times, B=400 \times$ ] 


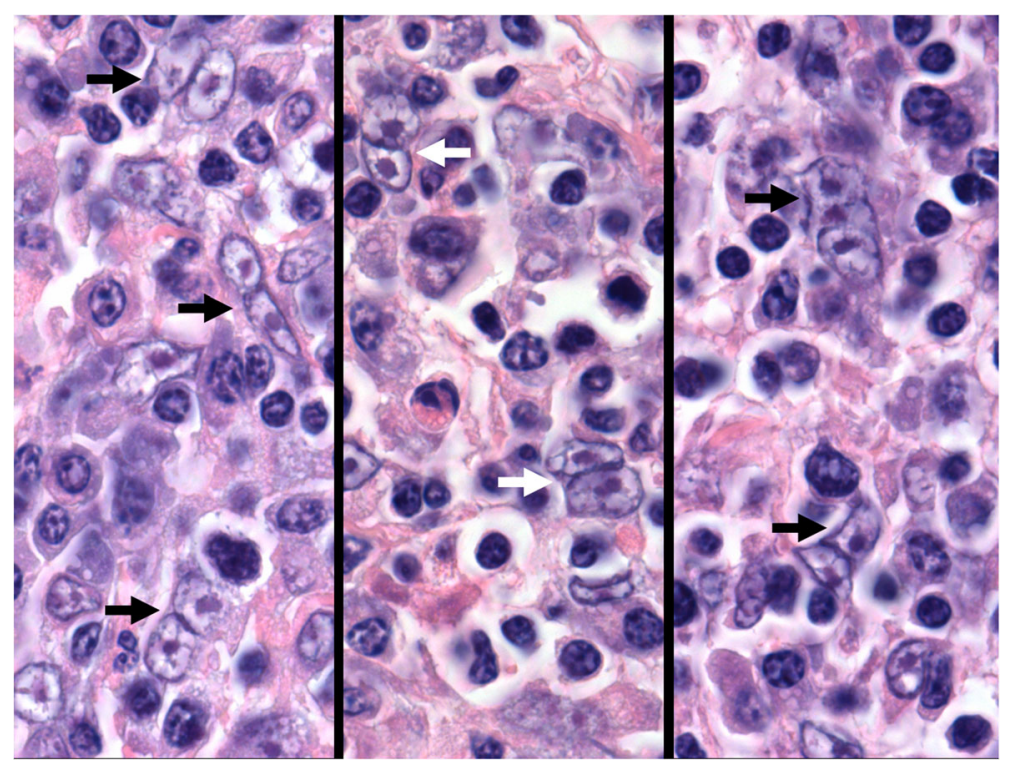

Fig. 3 Splenic IPT-like dendritic cell tumor. Intermingled with inflammatory cells, frequent neoplasitic follicular dendritic reticulum cells are indicated by arrows: bilobated nuclei contain clear chromatin and evident eosinophilic nucleoli; nuclear membrane is evident [H\&E, original magnification of all areas $=1000 \times]$

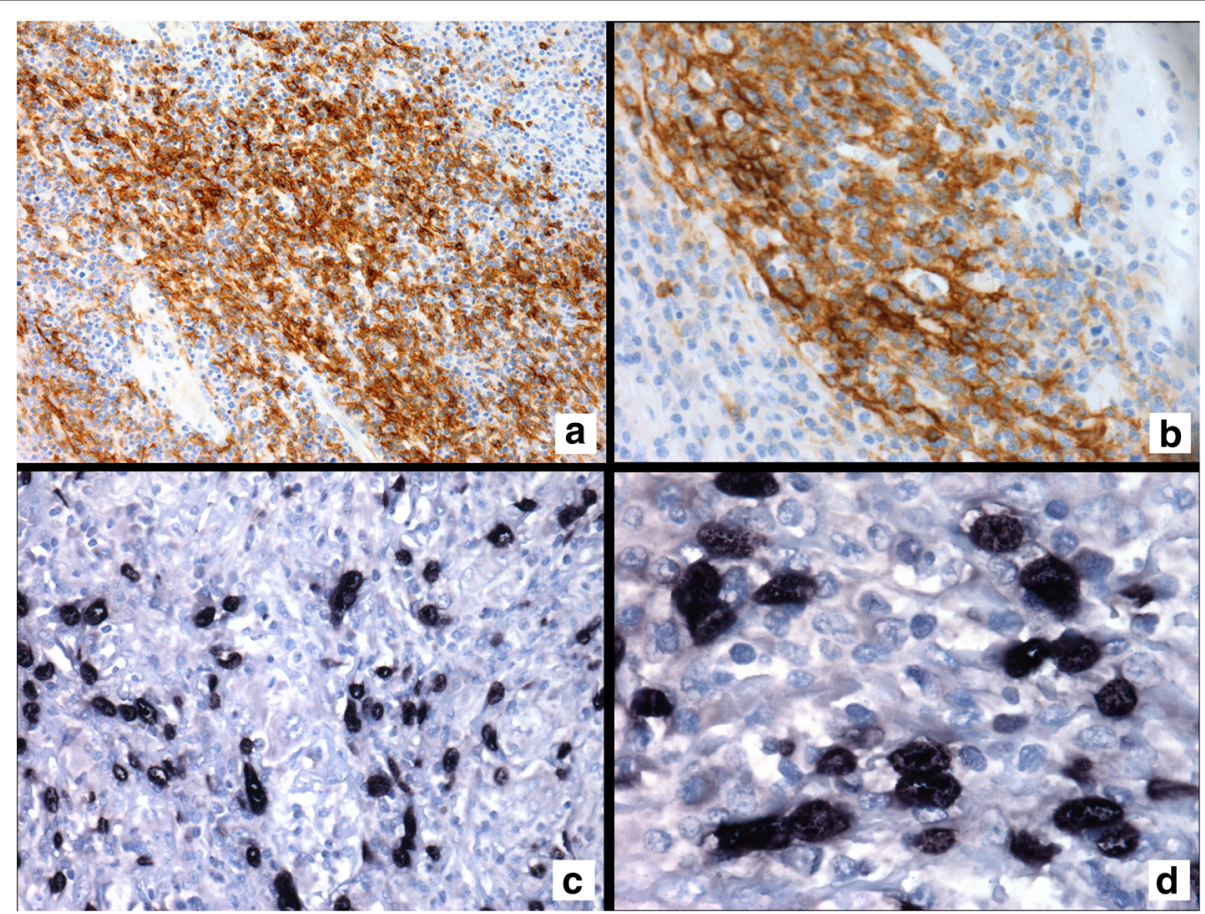

Fig. 4 Splenic IPT-like dendritic cell tumor. (a and b) Immunohistochemical expression of CD23 in neoplastic cells. (c and d) In situ hybridization shows the presence of EBV in the nuclei of neoplastic dendritic reticulum cells. Compare the nuclei highlighted in D with those of Fig. 3. [Original magnification $A=200 \times, B$ and $C=400 \times, D=1000 x]$ 


\section{Differential diagnoses}

The two cases presented herein, of the granulomatous variant of IPT-like FDCT, emphasize the need of including this subtype in the list of differential diagnoses of lesions constituted by spindle cell proliferation associated with significant inflammatory reaction. The first five cases of the granulomatous variant of IPT-like FDCT were recently reported by Li et al., 2014 [15]. The patients were mainly females (3 out of 5) with liver and/or splenic lesions. In four cases with available follow-up information, patients' outcome was favorable, without relapse. Immunohistochemical studies highlighted the expression of CD21 and CD35 in atypical spindle cells and the positivity for EBV in all cases $[11,15]$.

The main differential diagnoses are represented on one side by inflammatory lesions and, on the other side, by the conventional FDCT. Infectious processes or sarcoidosis represent essential differential diagnoses. Table 2 summarizes the main aspects in the differential diagnoses of IPTlike FDCT. In this context IPT may be also included, as it represents a lesion composed of ovoid to spindle cells admixed with polymorphic inflammatory cells, mostly $\mathrm{T}$ lymphocytes, but also B cells, plasma cells and histiocytes [16-18]. The nature of spindle cells in these lesions is still challenging because of their phenotypic variability. Inflammatory myofibroblastic tumor (IMT), a term which replaced most of the diagnoses of IPT in certain organs, should also be included in the differential diagnosis.

\section{Inflammatory pseudotumor and inflammatory myofibroblastic tumor}

Inflammatory pseudotumor (IPT) has become a misleading term, and it has been suggested that it should be avoided [19]. This expression is only descriptive and encompasses different entities, as inflammatory and infectious lesions (e. g., mycobacterial pseudotumor), and clonal processes, subsequently recognized as inflammatory myofibroblastic tumor (IMT) and IPT-like follicular dendritic cell tumor (FDCT) [18, 20-22]. Perhaps, a simply descriptive term, such as inflammatory spindle cell proliferation, would be more apropriate.

The evidence that lesions diagnosed as IPT were heterogeneous indicated that other terms should be given for the more aggressive cases, such as "Inflammatory fibrosarcoma of the mesentery and retroperitoneum" [23]. Later on, it was suggested that mesenterial and retroperitoneal fibosarcoma and IMT could be synonyms or closely related entities, as the latter may also recur and cause death [24]. In many early publications, IPT has been used as synonym or as a precursor term for IMT. These were lesions of the lungs, abdominal region, lymph nodes and spleen, and it soon became evident that IMT could be a clonal disorder, while IPT was not, especially in lymph nodes and spleen [24-27].
The finding of clonal alterations in IMT further supported the neoplastic nature of part of these lesions [2830]. However, the lack of specific markers, other than immunohistochemical detection of ALK, which is present in roughly half of the cases, limit diagnosis in daily practice [31, 32]. Using molecular methods, other genetic alterations have been described, as in ROS1, RET, and NTRK3, which account for part of ALK-negative IMT cases [33, 34]. Smooth muscle actin (SMA) is by no means marker for IMT, as its expression may be seen in other lesions, including FDC tumors [35].

The constant improvement in the characterization of inflammatory spindle cell proliferations makes it almost impossible to compare early reports on IPT, which might have included heterogeneous entities in the same category [36, 37]. Thus, the lack of clear-cut criteria may lead to confusion in histopathological classification of such lesions [32, 38]. Neuhauser et al. (2001) interpreted the expression of CD21 and LMP1/EBV in 2 of 12 cases of splenic IPT by stating that: "Although some of our cases showed a combination of spindled morphology, focal necrosis, and some immunophenotypic features described in association with FDC tumors, the presence of numerous plasma cells, bland appearance of the spindled cells, and benign clinical course supported the diagnosis of IMT. If IMT (IPT) and FDC tumors are related, it is possible that occasional cases with features of IMT may represent a less aggressive subset of FDC, with a graded myofibroblastic differentiation" [2].

In addition, Nonaka et al. (2005) suggested that IMT could be derived from follicular dendritic cells, for 5 reasons: 1) presence of inflammatory infiltrate, common in neoplasia of immunocompetent cells, as FDC; 2) existence of an IMT-like dendritic cell tumour; 3) overlap between lesions reported as IMT and lesions reported as tumours of follicular reticulum cells; 4) IMT complicating Castleman's disease; 5) proposed participation of reticulum cells in other inflammatory-rich spindle cell myofibroblastic-like process. Those authors affirmed that "It seems to us that this sum of observations, although far from conclusive, is suggestive enough of a probable involvement of follicular reticulum cells in IMT for the possibility to be further evaluated, especially if special markers of follicular reticulum cells were to become available" [32].

As specific markers are still missing, it is reasonable to approach diagnosis also on clinicopathological features. In this direction, most cases of inflammatory spindle cell proliferations of the lung and of the abdominal cavity of children have been considered IMT. As suggested elsewhere, features favoring the diagnosis of IMT include: younger age; topography in lung, soft tissue of abdomen, pelvis, retroperitoneum; diffuse inflammatory reaction 


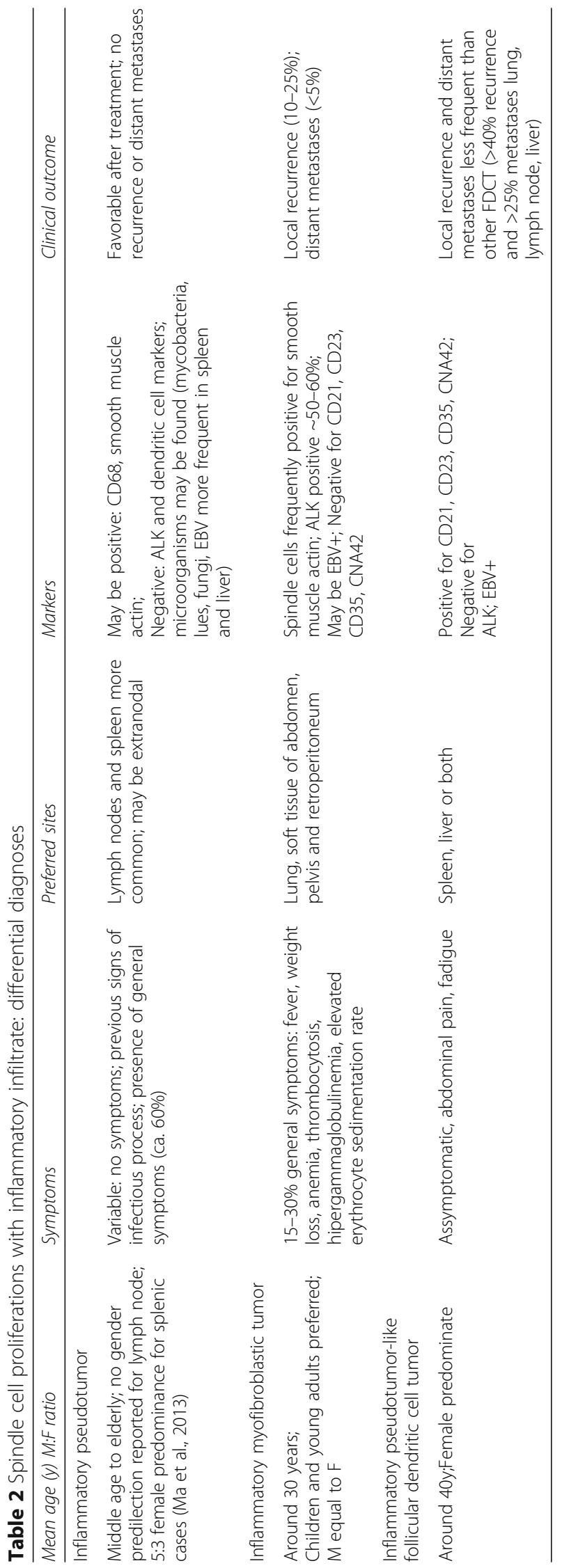


with conspicuous participation of plasma cells; nuclear atypia absent or mild; low mitotic rate; ALK positive immunohistochemistry or rearrangement. In contrast, older age, location in skin, lymph node, spleen, marked nuclear atypia, frequent mitoses, atypical mitoses and the presence of necrosis would support an alternative diagnosis $[19,39]$. The topographic distribution of IMT and the fibrosclerosing-inflammatory histology bring to mind IgG4-related sclerosing disease. Although IgG4positive plasma cells may be found in IMT, their amount is usually not so pronounced, although this criterion may not be used isolated [40]. In addition, IMT affects younger patients, is more circumscribed, presents less frequently lymphoid follicles, rarely shows obstructive phlebitis, and may be ALK positive [40, 41]. One of our cases (patient 1) presented high numbers of plasma cells in association with fibrotic bands (Fig. 2B). A relationship with IgG4 disease could be suggested, but no additional confirmatory immunohistochemical study could be made in this case. The support for the diagnosis of IMT included the presence of a circumscribed nodular mass, the expression profile, the lack of systemic lesions and the lack of obliterative phlebitis. Furthermore, these two diagnoses are more frequently subject of misdiagnosis in small biopsies [40].

\section{Inflammatory pseudotumor in lymph nodes and spleen}

IPT of the lymph nodes and spleen are rare lesions, and showed differences as compared to lesions in other sites. In a study of 5 cases, it was found that histologic alterations were mainly in the hilum, along the trabeculae, and in the capsule of the lymph node, extending at a variable degree into the parenchyma and the perinodal fat tissue [42]. Variable degree of lymph node involvement was also described in a series of 25 cases of IPT, staged from I to III, respectively, focal, partial and extensive [36]. Proportion of spindle and inflammatory cell components varied, predominating in some areas or mostly replaced by fibrous content in others. Lesions tended to follow the vascular axis, through the hilum $[16,43]$. Among the cases in which an etiological agent can be detected, pathologist should search for infection, especially for T. pallidum, as it has been shown that luetic lymphadenitis may also cause lymph node IPT $[18,44]$.

In a study of 11 cases of nodal IPT, no expression of ALK, CD21 and CD35 was found [26]. In addition, EBV was detected by in situ hybridization in one case, but only in infiltrating lymphocytes. Other reports on nodal IPT, similar lack of expression of FDC markers was described [43, 45].

A recent review on IPT of the spleen showed that these lesions are extremely rare, with a 5:3 female predominance [46]. EBV (in situ hybridization for EBER) has been found in spleen and liver IPT in higher frequency than in lymph node $(66 \%, 50 \%$ and $20 \%$, respectively $[20,38,47-50]$. Tuberculosis should be included in differential diagnosis [51], as well as sclerosing angiomatoid transformation of the spleen [52-54].

We retrieved 38 publications on splenic IPT, from 1984 (first description by Cotelingam \& Jaffe) to 2016 [2, 14, 20-22, 26, 38, 46, 47, 49, 50, 53, 55-81]. These reports corresponded to 69 cases, 43 female and 26 male (ratio 1.65:1), with median age of 56 years (range 6y to 81y). Seventeen cases have been published between years 1984 and 2000 and 52 from 2001 to date. In 32 cases there was information on immunohistochemical markers for follicular dendritic reticulum cells, being only six cases positive. However, the immunohistochemical panel was never extensive, and mostly included only CD21 and CD23. Information on EBV was available for 36 patients, with 24 positive cases. No positivity for ALK was detected among 18 patients for whom this protein was studied.

In some of these reports the terms IPT and IMT were used as synonyms [11, 14, 78]. In 8 publications, tumors were classified as splenic IMT: 8 patients, 4 male, 4 female, median age 40y (range 5-50y). In four patients there was information on EBV status, being only one case positive; ALK was tested in 7 cases and was positive in one; markers for follicular dendritic reticulum cells were tested in 4 cases, all of them negative [34, 82-88].

These data evidence the heterogeneity of immunohistochemical approach for IPT, hindering the assurance on the final diagnosis of each study, for comparison purposes.

\section{Follicular dendritic cell tumors of the spleen}

From 1996 to date we retrieved 22 publications reporting IPT-like FDC tumors [11, 15, 35, 89-107]. There were 46 patients described: 24 female, 22 male (ratio 1.1:1), median age 57y (range 29-79y). Five of these publications presented their 6 cases just as follicular dendritic cell tumor/ sarcoma. The most used markers for follicular dendritic reticulum cells were CD21, CD23 and CD35, with positive rates of $68 \%, 76 \%$ and $88 \%$, respectively. The value of these markers in the detection of FDRC was already acknowledged, especially CD35 [108]. Other markers used sporadically were: CNA.42, KiMp4, KiFDCp, fascin, CD14, clusterin and D2.40. CNA.42 has long been considered a reliable marker for FDRC [109]. Clusterin has also been proven a highly specific marker for FDC tumor, when strongly expressed, in opposition to fascin [110].

The presence of EBV in IPT-like FDC tumors is constant. Within the 22 publications retrieved, in only one out of 39 patients no EBV was detected. As informed above, 24 out of 36 patients diagnosed with splenic IPT were also positive for EBV. One may ask if some of these cases were in fact IPT-like FDC tumors, as only sporadically was the complete panel for these cells performed. 
It must be kept in mind that diagnosis of IPT-like FDC tumors should be very stringent, because not all of the most specific markers are $100 \%$ sensitive. Sometimes, enhancers of immunohistochemical detection may be needed [92]. This means that all of the markers should be tested in order to rule out the diagnosis of splenic FDC tumor: CD21, CD23, CD35, CNA.42, and clusterin. Detection of EBV using in situ hybridization is also mandatory, as it is almost $100 \%$ present in such tumors. Detection of ALK protein must also be performed, as expression of this protein should rule out the diagnosis of FDC tumor. In two reports on splenic IPT-like FDC tumors, high IgG4/IgG ratio was found $[35,98]$. Thus, in cases rich in plasma cells, this ratio should be also evaluated.

In regard to the neoplastic nature of FDC, it may be supported by some evidences. First, EBV was found to be clonal in splenic cases, as well as in primary liver IPT-like FDC tumors [93, 106, 111]. Also, although splenectomy is almost always curative, some cases present aggressive outcome, with local recurrence and/or lymph node infiltration [89, 104]. Morphological atypia and complex karyotype were also described in these tumors [92].

\section{Conclusions and highlights}

The diagnosis of fibro-inflammatory tumor proliferations may be difficult and require a combination of clinical, laboratory, topographic and pathological evidences;

The neoplastic nature of IMT and IPT-like FDC tumors is evidenced in part of the cases due to local recurrence or distant metastases, morphological atypia, and presence of clonality;

However, lack of such characteristics does not rule out both diagnoses, as total resection may be curative (cases of low malignancy), and clonality may be either absent or not routinely evaluated;

A large immunohistochemical panel for cell lineage markers and detection of EBV-RNA EBER sequences through CISH should be used, as no single specific and totally sensitive markers are available; this panel should be used in combination with other clinicopathological informations;

The term "IPT" does not represent a distinct diagnosis, and should be viewed as a descriptive one; a wide immunohistochemical panel and detection of EBV must be performed to exclude IMT and IPT-like FDC tumor.

\section{Abbreviations}

FDCT: Follicular dendritic cell tumor; IMT: Inflammatory myofibroblastic tumor; IPT: Inflammatory pseudotumor

\section{Acknowledgements}

Not applicable.

\section{Funding}

Not applicable.

\section{Availability of data and materials}

Slides of both cases and paraffin embedded tumor of case 2 available at the

Department of Anatomic Pathology, AC Camargo Cancer Center, Sao Paulo, Brazil.

\section{Authors' contributions}

All authors revised the manuscript critically for important intellectual context and gave final approval of the version to be published.

\section{Ethics approval and consent to participate}

The Committee of Ethics in Medical Research of AC Camargo Cancer Center, Sao Paulo, Brazil, approved the present publication.

\section{Consent for publication}

Not applicable.

\section{Competing interests}

The authors declare that they have no competing interest.

\section{Publisher's Note}

Springer Nature remains neutral with regard to jurisdictional claims in published maps and institutional affiliations.

Received: 6 September 2017 Accepted: 20 November 2017

Published online: 28 December 2017

\section{References}

1. Shia J, Chen W, Tang LH, Carlson DL, Quin J, Guillem JG, et al. Extranodal follicular dendritic cell sarcoma: clinical, pathologic, and histogenetic characteristics of an underrecognized disease entity. Virchows Arch. 2006:449:148-58.

2. Neuhauser TS, Derringer GA, Thompson LDR, Fanburg-Smith JC, Aguilera NSI, Andriko J, et al. Splenic inflammatory myofibroblastic tumor (inflammatory pseudotumor). A clinicopathologic and immunophenotypic study of 12 cases. Arch Path Lab Med. 2001;125:79-85.

3. Noguchi $\mathrm{H}$, Kondo $\mathrm{H}$, Kondo $\mathrm{M}$, Shiraiwa M, Monobe $\mathrm{Y}$. Inflammatory pseudotumor of the spleen. A case report. Jpn J Clin Oncol. 2000;30:196-203.

4. Facchetti F, Pileri SA, Lorenzi L, Tabanelli V, Rimsza L, Pittaluga S, et al. Histiocytic and dendritic cell neoplasms: what have we learnt by studying 67 cases. Virchow Arch. 2017; https://doi.org/10.1007/s00428-017-2176-1.

5. Schenka AA, De Angelo Andrade LA, Amstalden EM, Cintra ML, Vassallo J, Cardinalli IA, et al. Langerhans cell histiocytosis and its relationship with Epstein-Barr virus. Hum Pathol. 2006;37(11):1508-9. author reply 1509-1511

6. Ohtake $\mathrm{H}$, Yamakawa M. Interdigitating dendritic cell sarcoma and follicular dendritic cell sarcoma: histopathological findings for differential diagnosis. J Clin Exp Hematop. 2013;53(3):179-84.

7. Dalia S, Shao H, Sagatys E, Cualing H, Sokol L. Dendritic cell and histiocytic neoplasms: biology, diagnosis, and treatment. Cancer Control. 2014;21(4):290-300.

8. Goto N, Tsurumi H, Takami T, Futamura M, Morimitsu K, Takata K, et al. Cytokeratin-positive fibroblastic reticular cell tumor with follicular dendritic cell features: a case report and review of the literature. Am J Surg Pathol. 2015;39(4):573-80

9. Emile JF, Abla O, Fraitag S, Horne A, Haroche J, Donadieu J, et al. Revised classification of histiocytoses and neoplasms of the macrophage-dendritic cell lineages. Blood. 2016;127(22):2672-81.

10. Swerdlow SH, Campo E, Pileri SA, Harris NL, Stein H, Siebert R, et al. The 2016 revision of the World Health Organization classification of lymphoid neoplasms. Blood. 2016;127(20):2375-90.

11. Cheuk W, Chan JK, Shek TW, Chang JH, Tsou MH, Yuen NW, et al. Inflammatory pseudotumor-like follicular dendritic cell tumor: a distinctive low-grade malignant intra-abdominal neoplasm with consistent Epstein-Barr virus association. Am J Surg Pathol. 2001;25:721-31.

12. Krishnan J, Frizzera G. Two splenic lesions in need of clarification: hamartoma and inflammatory pseudotumor. Semin Diagn Pathol. 2003:20:94-104.

13. Chen WH, Liu TP, Liu CL, Tzen CY. Inflammatory pseudotumor of the spleen. J Chin Med Assoc. 2004;67:533-6.

14. Oshiro H, Nomura M, Yamanaka S, Watanabe S, Inayama Y. Splenic inflammatory pseudotumor (inflammatory myofibroblastic tumor). J Clin Exp Hematopathol. 2007:47:83-8. 
15. Li XQ, Cheuk W, Lam PW, Wang Z, Loong F, Yeong ML, et al. Inflammatory pseudotumor-like follicular dendritic cell tumor of liver and spleen: granulomatous and eosinophil-rich variants mimicking inflammatory or infective lesions. Am J Surg Pathol. 2014;38:646-53.

16. Menke DM, Griesser H, Araujo I, Foss HD, Herbst H, Banks PM, Stein H. Inflammatory Pseudotumors of Lymph Node Origin Show MacrophageDerived Spindle Cells and Lymphocyte-Derived Cytokine Transcripts Without Evidence of T-Cell Receptor Gene Rearrangements. Implications for Pathogenesis and Classification as an Idiopathic Retroperitoneal Fibrosis-Like Sclerosing Immune Reaction. Am J Clin Pathol. 1996;105:430-9.

17. Cheuk W, Woo PC, Yuen KY, Yu PH, Chan JK. Intestinal inflammatory pseudotumour with regional lymph node involvement: identification of a new bacterium as the aetiological agent. J Pathol. 2000;192:289-92.

18. Androulaki A, Papathomas TG, Liapis G, Papaconstantinou I, Gazouli M, Goutas N, et al. Inflammatory pseudotumor associated with Mycobacterium tuberculosis infection. Int I Infect Dis. 2008;12:607-10.

19. Gleason BC, Hornick JL. Inflammatory myofibroblastic tumours: where are we now. J Clin Pathol. 2008;61(4):428-37.

20. Arber DA, Kamel OW, van de Rijn M, Davis RE, Medeiros $\sqcup$, Jaffe ES, Weiss LM. Frequent presence of the Epstein-Barr virus in inflammatory pseudotumor. Hum Pathol. 1995:26(10):1093-8.

21. Braun B, Cazorla A, Rivas C, Gárgolas M, Fernández-Guerrero M. Inflammatory pseudotumor of the spleen in a patient with human immunodeficiency virus infection: a case report and review of the literature. Ann Hematol. 2003:82(8):511-4.

22. Zhang MQ, Lennerz JK, Dehner LP, Brunt LM, Wang HL. Granulomatous inflammatory pseudotumor of the spleen: association with Epstein-Barr virus. Appl Immunohistochem Mol Morphol. 2009;17(3):259-63.

23. Meis JM, Enzinger FM. Inflammatory fibrosarcoma of the mesentery and retroperitoneum. A tumor closely simulating inflammatory pseudotumor. Am J Surg Pathol. 1991;15(12):1146-56.

24. Coffin CM, Dehner LP, Meis-Kindblom JM. Inflammatory myofibroblastic tumor, inflammatory fibrosarcoma, and related lesions: an historical review with differential diagnostic considerations. Semin Diagn Pathol. 1998;15(2):102-110.

25. Thomas RM, Jaffe ES, Zarate-Osorno A, Medeiros LJ. Inflammatory pseudotumor of the spleen. A clinicopathologic and immunophenotypic study of eight cases. Arch Pathol Lab Med. 1993;117(9):921-6.

26. Kutok JL, Pinkus GS, Dorfman DM, Fletcher CD. Inflammatory pseudotumor of lymph node and spleen: an entity biologically distinct from inflammatory myofibroblastic tumor. Hum Pathol. 2001;32(12):1382-7.

27. Dehner LP. Inflammatory myofibroblastic tumor: the continued definition of one type of so-called inflammatory pseudotumor. Am J Surg Pathol. 2004:28(12):1652-4.

28. Treissman SP, Gillis DA, Lee CL, Giacomantonio M, Resch L. Omentalmesenteric inflammatory pseudotumor. Cytogenetic demonstration of genetic changes and monoclonality in one tumor. Cancer. 1994;73(5):1433-7.

29. Su LD, Atayde-Perez A, Sheldon S, Fletcher JA, Weiss SW. Inflammatory myofibroblastic tumor: cytogenetic evidence supporting clonal origin. Mod Pathol. 1998;11(4):364-8.

30. Griffin CA, Hawkins AL, Dvorak C, Henkle C, Ellingham T, Perlman EJ. Recurrent involvement of $2 p 23$ in inflammatory myofibroblastic tumors. Cancer Res. 1999:59(12):2776-80.

31. Cook JR, Dehner LP, Collins MH, Ma Z, Morris SW, Coffin CM, Hill DA. Anaplastic lymphoma kinase (ALK) expression in the inflammatory myofibroblastic tumor: a comparative immunohistochemical study. Am J Surg Pathol. 2001;25(11):1364-71.

32. Nonaka D, Birbe R, Rosai J. So-called inflammatory myofibroblastic tumour: a proliferative lesion of fibroblastic reticulum cells? Histopathology. 2005:46(6):604-13.

33. AntonesCu CR, Suurmeijer AJ, Zhang L, Sung YS, Jungbluth AA, Travis WD, et al. Molecular characterization of inflammatory myofibroblastic tumors with frequent ALK and ROS1 gene fusions and rare novel RET rearrangement. Am J Surg Pathol. 2015;39(7):957-67.

34. Yamamoto H, Yoshida A, Taguchi K, Kohashi K, Hatanaka Y, Yamashita A, et al. ALK, ROS1 and NTRK3 gene rearrangements in inflammatory myofibroblastic tumours. Histopathology. 2016;69(1):72-83.

35. Choe JY, Go H, Jeon YK, Yun JY, Kim YA, Kim HJ, et al. Inflammatory pseudotumor-like follicular dendritic cell sarcoma of the spleen: a report of six cases with increased lgG4-positive plasma cells. Pathol Int. 2013;63(5):245-51.
36. Moran CA, Suster S, Abbondanzo SL. Inflammatory pseudotumor of lymph nodes: a study of 25 cases with emphasis on morphological heterogeneity. Hum Pathol. 1997;28(3):332-8.

37. Dehner LP. The enigmatic inflammatory pseudotumours: the current state of our understanding, or misunderstanding. J Pathol. 2000;192(3):277-9.

38. Rosenbaum L, Fekrazad MH, Rabinowitz I, Vasef MA. Epstein-Barr virusassociated inflammatory pseudotumor of the spleen: report of two cases and review of the literature. J Hematop. 2009;2(2):127-31.

39. Coffin CM, Watterson J, Priest JR, Dehner LP. Extrapulmonary inflammatory myofibroblastic tumor (inflammatory pseudotumor). A clinicopathologic and immunohistochemical study of 84 cases. Am J Surg Pathol. 1995;19(8):859-72.

40. Saab ST, Hornick JL, Fletcher CD, Olson SJ, Coffin CM. IgG4 plasma cells in inflammatory myofibroblastic tumor: inflammatory marker or pathogenic link. Mod Pathol. 2011;24(4):606-12.

41. Yamamoto H, Yamaguchi H, Aishima S, Oda Y, Kohashi K, Oshiro Y, Tsuneyoshi M. Inflammatory myofibroblastic tumor versus lgG4-related sclerosing disease and inflammatory pseudotumor: a comparative clinicopathologic study. Am J Surg Pathol. 2009;33(9):1330-40.

42. Facchetti F, De Wolf PC, De Wever I, Frizzera G. Inflammatory pseudotumor of lymph nodes. Immunohistochemical evidence for its fibrohistiocytic nature. Am J Pathol. 1990;137(2):281-9.

43. New NE, Bishop PW, Stewart M, Banerjee SS, Harris M. Inflammatory pseudotumour of lymph nodes. J Clin Pathol. 1995;48(1):37-40.

44. Facchetti F, Incardona P, Lonardi S, Fisogni S, Legrenzi L, Chioda C, Ponzoni M, Chiodera PL. Nodal inflammatory pseudotumor caused by luetic infection. Am J Surg Pathol. 2009;33(3):447-53.

45. Kojima M, Nakamura S, Shimizu K, Hosomura Y, Ohno Y, Itoh H, et al. Inflammatory pseudotumor of lymph nodes: clinicopathologic and immunohistological study of 11 Japanese cases. Int J Surg Pathol. 2001;9(3):207-14.

46. Ma ZH, Tian XF, Ma J, Zhao YF. Inflammatory pseudotumor of the spleen: A case report and review of published cases. Oncol Lett. 2013;5(6):1955-7.

47. Yamaguchi M, Yamamoto T, Tate G, Matsumoto T, Matsumiya A, Kuzume M, et al. Specific detection of Epstein-Barr virus in inflammatory pseudotumor of the spleen in a patient with a high serum level of soluble IL-2 receptor. J Gastroenterol. 2000;35(7):563-6.

48. Ise N, Miyazawa H, Satoh S, lida M, Uchinami H, Kume M, et al. Epstein-Barr virus-positive inflammatory pseudotumor of the spleen managed with laparoscopic splenectomy. Clin J Gastroenterol. 2008;1 (4):164-7.

49. Loughlin P, Brady A, Devlin E, McManus DT, Spence RA. Epstein-Barr virus positive inflammatory pseudo-tumour of the spleen: A case report and literature review. Int J Surg Case Rep. 2014;5(4):186-8.

50. You Y, Shao H, Bui K, Bui M, Klapman J, Cui Q, Coppola D. Epstein-Barr virus positive inflammatory pseudotumor of the liver: report of a challenging case and review of the literature. Ann Clin Lab Sci. 2014;44(4):489-98.

51. Prieto-Nieto MI, Pérez-Robledo JP, Díaz-San Andrés B, Nistal M, RodríguezMontes JA. Inflammatory pseudotumour of the spleen associated with splenic tuberculosis. World J Gastrointest Surg. 2014;6(12):248-52.

52. Diebold J, Le Tourneau A, Marmey B, Prevot S, Müller-Hermelink HK, Sevestre $\mathrm{H}$, et al. Is sclerosing angiomatoid nodular transformation (SANT) of the splenic red pulp identical to inflammatory pseudotumour? Report of 16 cases. Histopathology. 2008:53:299-310.

53. Kashiwagi S, Kumasaka T, Bunsei N, Fukumura Y, Yamasaki S, Abe S. Detection of Epstein-Barr virus-encoded small RNA-expressed myofibroblasts and IgG4-producing plasma cells in sclerosing angiomatoid nodular transformation of the spleen. Virchows Arch. 2008;453:275-82.

54. Vyas M, Deshmukh M, Shet T, Jambhekar N. Splenic angiomatoid nodular transformation in child with inflammatory pseudotumor-like areas. Indian J Pathol Microbiol. 2011;54(4):829-31.

55. Cotelingam JD, Jaffe ES. Inflammatory pseudotumor of the spleen. Am J Surg Pathol. 1984;8(5):375-80.

56. McMahon RF. Inflammatory pseudotumour of spleen. J Clin Pathol. 1988:41(7):734-6.

57. Sheahan K, Wolf BC, Neiman RS. Inflammatory pseudotumor of the spleen: a clinicopathology study of three cases. Hum Pathol. 1988;19(9):1024-9.

58. Wiernik PH, Rader M, Becker NH, Morris SF. Inflammatory pseudotumor of spleen. Cancer. 1990;66(3):597-600.

59. Monforte-Muñoz H, Ro JY, Manning JT Jr, Landon G, Del Junco G, Carlson TS, Ayala AG. Inflammatory pseudotumor of the spleen. Report of two cases with a review of the literature. Am J Clin Pathol. 1991;96(4):491-5. 
60. Inada T, Yano T, Shima S, Ishikawa Y, Irie S, Ishida M, et al. Inflammatory pseudotumor of the spleen. Intern Med. 1992;31(7):941-5.

61. Yeung E, Hugh TB, Rainer S. Inflammatory pseudotumour of the spleen. Aust N Z J Surg. 1996;66(7):492-3.

62. Noguchi H, Kondo H, Kondo M, Shiraiwa M, Monobe Y. Inflammatory pseudotumor of the spleen: a case report. Jpn J Clin Oncol. 2000;30(4):196-203.

63. Moriyama S, Inayoshi A, Kurano R. Inflammatory pseudotumor of the spleen: report of a case. Surg Today. 2000;30(10):942-6.

64. Ozkara SK, Gürbüz Y, Erçín C, Müezzínoğlu B, Türkmen M. Inflammatory pseudotumor of the spleen. Virchows Arch. 2001;438(6):629-31.

65. Lewis JT, Gaffney RL, Casey MB, Farrell MA, Morice WG, Macon WR. Inflammatory pseudotumor of the spleen associated with a clonal EpsteinBarr virus genome. Case report and review of the literature. Am J Clin Pathol. 2003;120(1):56-61.

66. Sarker A, An C, Davis M, Praprotnik D, McCarthy LJ, Orazi A. Inflammatory pseudotumor of the spleen in a 6-year-old child: a clinicopathologic study. Arch Pathol Lab Med. 2003;127(3):e127-30.

67. Yano H, Imasato M, Monden T, Okamoto S. Inflammatory pseudotumor of the spleen: report of two cases. Surgery. 2003:133(3):349-50.

68. Oz Puyan F, Bilgi S, Unlu E, Yalcin O, Altaner S, Demir M, Cakir B. Inflammatory pseudotumor of the spleen with EBV positivity: report of a case. Eur J Haematol. 2004;72(4):285-91.

69. Hatsuse M, Murakami S, Haruyama H, Inaba T, Shimazaki C. Inflammatory pseudotumor of the spleen complicated by idiopathic thrombocytopenic purpura. Ann Hematol. 2005;84(9):619-20.

70. Uchida H, Ohta M, Shibata K, Endo Y, Iwaki K, Tominaga M, et al. Laparoscopic splenectomy in patients with inflammatory pseudotumor of the spleen: Report of 2 cases and review of the literature. Surg Laparosc Endosc Percutan Tech. 2006;16(3):182-6.

71. Takamoto K, Midorikawa Y, Minagawa M, Makuuchi M. Inflammatory pseudotumor of the spleen: clinical impact in surgical treatment. Biosci Trends. 2007:1(2):113-6.

72. Yan J, Peng C, Yang W, Wu C, Ding J, Shi T, Li H. Inflammatory pseudotumour of the spleen: report of 2 cases and literature review. Can J Surg. 2008;51(1):75-6.

73. Martínez-Delgado C, Ocaña L, Estrada DG, Sánchez-Carrillo JJ, Palacios R. Inflammatory pseudotumor of the liver and spleen. Clin J Gastroenterol. 2011:4(4):233-5.

74. Tsutsumi N, Kawanaka H, Yamaguchi S, Sakai M, Momosaki S, Endo K, Ikejiri K. Huge inflammatory pseudotumor of the spleen with postoperative portal vein thrombosis: report of a case. Surg Today. 2012;42(4):382-5.

75. Rajabi P, Noorollahi H, Hani M, Bagheri M. Inflammatory pseudotumor of spleen. Adv Biomed Res. 2014;3:29.

76. Klimis T, Mylonakis E, Kostourou A, Vlachos G, Glynatsis M. A Case of Inflammatory Pseudotumour of the Spleen with EBV Infection Complicated by Idiopathic Thrombocytopenic Purpura. Hellenic Journal of Surgery. 2013;85(6):403-7.

77. Kalaivani V, Vijayakumar HM, Girish KS, Nishchit H. Inflammatory Pseudotumour of the Spleen: A Diagnostic Dilemma. J Clin Diagn Res. 2013;7(7):1460-2.

78. Palomeque Jiménez A, Reyes Moreno M, Calzado Baeza S, Ranea Jimena SA, Robayo Soto PS. Detection of Epstein-Barr virus in an inflammatory myofibroblastic tumor of the spleen (inflammatory pseudotumor). Cir Esp. 2015;93(6):e41-3.

79. McMahon G, Rady K, Prince HM. Inflammatory pseudotumor. Hematology Reports. 2015;7(5905):35-7.

80. Ugalde P, Bernardo CG, Granero P, Miyar A, Gonzalez C, Gonzalez-Pinto I, et al. Inflammatory pseudotumor of spleen: a case report. Int J Surg Case Reports. 2015;7:145-8.

81. Mance M, Romić I, Majerović M. Detection of Epstein-Barr virus in inflammatory pseudotumour of the spleen: a case report. Wien Klin Wochenschr. 2016;128(11-12):442-6.

82. Mosunjac MB, Feliciano DV, Majmudar B. Pathologic quiz case: a mass of the spleen. Inflammatory myofibroblastic tumor of the spleen. Arch Pathol Lab Med. 2001;125(12):1607-8.

83. Gasljević G, Lamovec J. Malignant lymphoma of the stomach in association with inflammatory myofibroblastic tumor of the spleen. A case report. Pathol Res Pract. 2003;199(11):745-9.

84. Dall'Igna P, Cecchetto G, Guglielmi M, Alaggio R. Clinical and pathologic considerations in a case of inflammatory myofibroblastic tumor of the spleen. Pediatr Surg Int. 2004;20(11-12):875-7.
85. Chen HW, Lai EC, Huang XJ, Chen FN, Lu RL, Pan AZ, Lau WY. Inflammatory myofibroblastic tumours of the spleen and liver. Asian J Surg. 2008;31(1):25-8

86. Krl EA, Orhan D, Haliloğlu M, Karnak I. Invasive inflammatory myofibroblastic tumor of the spleen treated with partial splenectomy in a child. J Pediatr Hematol Oncol. 2012;34(4):e131-3.

87. Chen WC, Jiang ZY, Zhou F, Wu ZR, Jiang GX, Zhang BY, Cao LP. A large inflammatory myofibroblastic tumor involving both stomach and spleen: A case report and review of the literature. Oncol Lett. 2015;9(2):811-5.

88. Koechlin L, Zettl A, Koeberle D, von Flüe M, Bolli M. Metastatic Inflammatory Myofibroblastic Tumor of the Spleen: A Case Report and Review of the Literature. Case Rep Surg. 2016;2016:8593242.

89. Perez-Ordonez B, Erlandson RA, Rosai J. Follicular dendritic cell tumor: report of 13 additional cases of a distinctive entity. Am J Surg Pathol. 1996:20(8):944-55.

90. Horiguchi H, Matsui-Horiguchi M, Sakata H, Ichinose M, Yamamoto T, Fujiwara M, Ohse H. Inflammatory pseudotumor-like follicular dendritic cell tumor of the spleen. Pathol Int. 2004;54(2):124-31.

91. Brittig F, Ajtay E, Jaksó P, Kelényi G. Follicular dendritic reticulum cell tumor mimicking inflammatory pseudotumor of the spleen. Pathol Oncol Res. 2004:10(1):57-60.

92. Sander B, Middel P, Gunawan B, Schulten HJ, Baum F, Golas MM, et al. Follicular dendritic cell sarcoma of the spleen. Hum Pathol. 2007;38(4):668-72

93. Laurent C, Meggetto F, de Paiva GR, Selves J, Palasse J, Laurent G, Brousset $P$. Follicular dendritic cell tumor of the spleen associated with diffuse large B-cell lymphoma. Hum Pathol. 2008;39(5):776-80.

94. Kim HJ, Kim JE, Kang GH, Kim JY, Park K. Inflammatory Pseudotumor-like Follicular Dendritic Cell Tumor of the Spleen with Extensive Histiocytic Granulomas and Necrosis: A Case Report and Literature Review. Korean J Pathol. 2013;47(6):599-602

95. Ge R, Liu C, Yin X, Chen J, Zhou X, Huang C, et al. Clinicopathologic characteristics of inflammatory pseudotumor-like follicular dendritic cell sarcoma. Int J Clin Exp Pathol. 2014;7(5):2421-9.

96. Vardas K, Manganas D, Papadimitriou G, Kalatzis V, Kyriakopoulos G, Chantziara $\mathrm{M}$, et al. Splenic inflammatory pseudotumor-like follicular dendritic cell tumor. Case Rep Oncol. 2014;7(2):410-6.

97. Foix MP, Martin LF, Esteller FC, Zambrano MI. EBV-associated inflammatory pseudotumor-like follicular dendritic cell sarcoma of the spleen. Virchows Archiv. 2014:465(Suppl. 1):S279-80.

98. Zehani-Kassar A, Chelly I, Azouz H, Rekik W, Haouet S, Kchir N. Inflammatory pseudotumor-like dendritic cell sarcoma of the spleen. Virchows Archiv. 2014;465(Suppl. 1):S274

99. Nguyen BD, Roarke MC, Yang M. Synchronous hepatic and splenic inflammatory pseudotumour-like follicular dendritic cell sarcomas. Liver Int. 2015;35:1917.

100. Bui PL, Vicens RA, Westin JR, Jensen CT. Multimodality imaging of EpsteinBarr virus-associated inflammatory pseudotumor-like follicular dendritic cell tumor of the spleen: case report and literature review. Clin Imaging. 2015;39(3):525-8.

101. Kitamura Y, Takayama Y, Nishie A, Asayama Y, Ushijima Y, Fujita N, et al. Inflammatory Pseudotumor-like Follicular Dendritic Cell Tumor of the Spleen: Case Report and Review of the Literature. Magn Reson Med Sci. 2015;14(4):347-54.

102. Nishiyama R, Baba S, Watahiki Y, Maruo H. Inflammatory pseudotumour-like follicular dendritic cell tumour of the spleen. BMJ Case Rep. 2015;2015:pii: bcr2014206373.

103. Chen Y, Shi H, Li H, Zhen T, Han A. Clinicopathological features of inflammatory pseudotumour-like follicular dendritic cell tumour of the abdomen. Histopathology. 2016;68(6):858-65.

104. Agaimy A, Michal M, Hadravsky L, Michal M. Follicular dendritic cell sarcoma: clinicopathologic study of 15 cases with emphasis on novel expression of MDM2, somatostatin receptor 2A, and PD-L1. Ann Diagn Pathol. 2016;23:21-8.

105. Wang L, Xu D, Qiao Z, Shen L, Dai H, Ji Y. Follicular dendritic cell sarcoma of the spleen: A case report and review of the literature. Oncol Lett. 2016;12(3):2062-4.

106. Liang J, Chen Y, Zhang F, Shi H, Dong Y, Li H, et al. Genomic variation of Epstein-Barr virus in inflammatory pseudotumor-like follicular dendritic cell tumor. Histopathology. 2016;69(5):883-4.

107. Hang JF, Wang LC, Lai CR. Cytological features of inflammatory pseudotumor-like follicular dendritic cell sarcoma of spleen: A case report. Diagn Cytopathol. 2017:45(3):230-4 
108. Bagdi E, Krenacs L, Krenacs T, Miller K, Isaacson PG. Follicular dendritic cells in reactive and neoplastic lymphoid tissues: a reevaluation of staining patterns of CD21, CD23, and CD35 antibodies in paraffin sections after wet heat-induced epitope retrieval. Appl Immunohistochem Mol Morphol. 2001;9(2):117-24.

109. Raymond I, Al Saati T, Tkaczuk J, Chittal S, Delsol G. CNA.42, a new monoclonal antibody directed against a fixative-resistant antigen of follicular dendritic reticulum cells. Am J Pathol. 1997;151(6):1577-85.

110. Grogg KL, Macon WR, Kurtin PJ, Nascimento AG. A survey of clusterin and fascin expression in sarcomas and spindle cell neoplasms: strong clusterin immunostaining is highly specific for follicular dendritic cell tumor. Mod Pathol. 2005;18(2):260-6.

111. Selves J, Meggetto F, Brousset P, Voigt JJ, Pradère B, Grasset D, et al. Inflammatory pseudotumor of the liver. Evidence for follicular dendritic reticulum cell proliferation associated with clonal Epstein-Barr virus. Am J Surg Pathol. 1996;20(6):747-53.

Submit your next manuscript to BioMed Central and we will help you at every step:

- We accept pre-submission inquiries

- Our selector tool helps you to find the most relevant journal

- We provide round the clock customer support

- Convenient online submission

- Thorough peer review

- Inclusion in PubMed and all major indexing services

- Maximum visibility for your research

Submit your manuscript at www.biomedcentral.com/submit
Biomed Central 